\title{
Um sermão fillosófico travestido de conhecimento social: a etnografia da ciência de Bruno Latour
}

LUÍS DE GUSMÃ̃"

\section{Resumo}

O artigo apresenta uma reflexão sobre a crítica da epistemologia normativa levada a cabo por Bruno Latour em seus estudos da comunidade científica, com mais exatidão nos livros A vida de laboratório e Ciência em ação, sublinhando basicamente duas dificuldades internas dessa crítica, a saber: 1) na etnografia da ciência desenvolvida por Latour, a abordagem normativa, ao contrário do prometido ao leitor, não cede lugar à abordagem empírica, pois a caracterização da "tribo dos cientistas" ali oferecida permanece clara e inequivocamente valorativa; 2) nessa etnografia, temos, ao mesmo tempo, o recurso metodológico explícito ao empirismo enquanto lógica geral de validação de alcance transcontextual e a defesa da tese de acordo com a qual a validação das conclusões da ciência pode ser explicada, de forma exaustiva, com base em variáveis contextuais, coisas logicamente incompatíveis. Nesse sentido, Latour acaba de fato fracassando em sua tentativa de superar, por meio da pesquisa etnográfica, a distinção formulada pela epistemologia normativa entre explicação empírica e justificação racional do conhecimento humano.

Palavras-chave: Epistemologia normativa. Etnografia da ciência. Comunidade científica. Explicação empírica.

\footnotetext{
* Universidade de Brasília, Brasil
} 


\title{
A philosophical sermon disguised as social knowledge: Bruno Latour's ethnography of science
}

\begin{abstract}
The article offers a reflection on the criticism of normative epistemology carried out by Bruno Latour in his studies of the scientific community, particularly in Laboratory Life and Science in action, highlighting two internal difficulties in this criticism, namely: 1) in the ethnography of science developed by Latour, unlike promised to the reader, the normative approach does not give way to the empirical approach, since the characterization of the "tribe of scientists" offered there remains clear and unequivocally evaluative; 2 ) in this ethnography, we have, concurrently, the explicit methodological recourse to empiricism as a general logic of validation of trans-contextual scope, and the defense of the hypothesis that the validation of scientific findings can be exhaustively explained in terms of contextual variables, things that are logically incompatible. Thus, Latour has indeed failed in his attempt, by means of ethnographic research, to overcome the distinction formulated by normative epistemology between empirical explanation and rational justification of human knowledge.
\end{abstract}

Keywords: Normative epistemology. Ethnography of science. Scientific community. Empirical explanation 


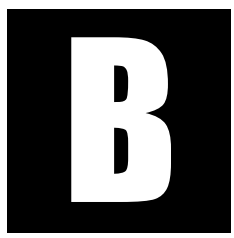

runo Latour é hoje um dos sociólogos contemporâneos mais influentes e conhecidos, apesar de abordar, em algumas de suas principais obras, temas relativamente restritos, tais como os bastidores da comunidade científica e os fatores responsáveis pelo encerramento de controvérsias no interior dessa comunidade. Seus livros têm sido traduzidos e divulgados, e seu nome costuma ser associado aos avanços mais significativos em sociologia do conhecimento. Latour parece seduzir sociólogos e antropólogos pela postura irreverente e desmistificadora assumida em face do mundo das ciências naturais: contra uma reflexão epistemológica que insistia em idealizar tal mundo, ao identificá-lo como o domínio por excelência de uma racionalidade abstrata, desenraizada, colocada acima das paixões, valores e interesses de indivíduos situados em contextos sociais particulares, Latour viria sublinhar sua dimensão humana, demasiado humana. E faria isso com base em circunstanciadas investigações empíricas da "vida de laboratório", da "ciência em ação". Num contraste vivo com a "velha" sociologia do conhecimento, exemplarmente representada na figura de Merton, a "nova", tão bem expressa por Latour, já não admitiria deixar para os epistemólogos, autoproclamados guardiões da razão pura, a tarefa de esclarecer o curso bem-sucedido da pesquisa científica, limitando-se a uma análise das determinações sociais do erro intelectual. A sociologia do conhecimento levada a cabo por Latour implicaria a rejeição radical dessa divisão de tarefas com os epistemólogos - uma divisão aceita, em larga medida, no passado -, quando se tratava de tornar inteligíveis os erros e acertos da comunidade científica. Do ponto de vista epistemológico, os acertos e sucessos científicos expressariam invariavelmente o triunfo mais completo da razão, concebida em termos de consistência lógica e recurso ao tribunal da experiência na avaliação das alegações de conhecimento. Em contrapartida, os erros e desatinos da 
comunidade científica evidenciariam colapsos da racionalidade ocorridos em circunstâncias particulares a ser elucidadas por estudos empíricos, aí incluída a investigação sociológica. Em aberta oposição a este ponto de vista, identificado como um sermão filosófico distanciado das práticas reais dos pesquisadores, Latour, sintonizado aqui com as tendências mais recentes da sociologia do conhecimento, buscaria explicar os êxitos da ciência a partir de uma etnografia da comunidade científica capaz de apreender o saber científico - real, e não idealizado - em construção.

Nessa perspectiva, não só os erros e desatinos, mas também as mais celebradas conquistas da ciência - até então tema exclusivo da reflexão epistemológica - exigiam explicações empíricas. Em outras palavras, a sociologia do conhecimento deveria ser, conforme Bloor, "imparcial com respeito à verdade e à falsidade". Com isso, pouco ou nada restaria para uma epistemologia apriorística e normativa que teimava em estabelecer conclusões definitivas acerca do mundo da ciência, sem nele efetivamente adentrar. Latour representaria um salutar e bem-vindo abandono, no âmbito dos estudos sobre a ciência, de filosofices moralizantes, em favor de um relato empírico, ancorado nos fatos, daquilo que se passava no interior da comunidade científica. Já não soava plausível buscar compreender a ciência recorrendo a uma disciplina situada de fato fora e presumidamente acima das ciências empíricas particulares, disciplina mais apta, em decorrência disso, a produzir sermões, a brandir tábuas de proibições e diretrizes metodológicas irrealistas do que a oferecer explicações genuínas da vida de laboratório. Em linhas gerais, este parece ser o significado atribuído por Latour ao seu próprio trabalho, mais exatamente aos seus estudos sobre a "ciência em ação". Investigadores sociais descrentes da velha epistemologia são levados a aceitar com simpatia as ideias de Latour, ao interpretá-las dessa maneira. Para eles, a sociologia da ciência de Latour testemunharia um adeus às ilusões da reflexão epistemológica, 
em benefício de uma abordagem resolutamente "naturalista", empírica e não normativa, das práticas reais desenvolvidas na comunidade real dos cientistas. Isso talvez explique, em considerável medida, o sucesso dessa sociologia, a acolhida favorável que vem recebendo entre pesquisadores sociais de reconhecida competência e seriedade.

Nos limites deste artigo, formularemos basicamente duas objeções à sociologia da ciência desenvolvida nos livros $A$ vida de laboratório e Ciência em ação. E apenas neles, leitor: não estamos nem um pouco interessados, por razões que ficarão muito visíveis mais adiante, em analisar possíveis desdobramentos e/ou reformulações da obra de Bruno Latour. A primeira objeção é a de que a pretendida ruptura com o ponto de vista normativo dos epistemólogos, associado a uma visão irrealista, complacente e apologética da comunidade científica, na realidade não ocorre, pois a sociologia de Latour permanece prisioneira da problemática normativa relativa à avaliação do conhecimento científico, uma problemática constitutiva da velha epistemologia rejeitada, mas totalmente estranha às investigações empíricas. A segunda objeção diz respeito a uma imperdoável inconsistência: Latour censura os epistemólogos por postularem uma lógica geral de validação dos enunciados, irredutível a contextos sociais particulares, mas acaba por acolher exatamente algo assim, todas as vezes que reivindica conteúdos empíricos para seu trabalho etnográfico, acusando os adversários de esgrimirem fantasias carentes desse conteúdo. A fim de tornar mais clara a distinção entre uma abordagem normativa, típica dos filósofos, e uma abordagem empírica do mundo da ciência, vale a pena examinar a famosa polêmica envolvendo Popper e Kuhn, polêmica na qual essa distinção soa particularmente nítida. Este o nosso próximo passo. 


\section{Distinção entre abordagens normativas e empíricas do conhecimento científico: a polêmica entre Popper e Kuhn}

A teoria geral do método desenvolvida por Karl Popper em A lógica da pesquisa científica (1993) constitui, talvez, a expressão mais coerente e acabada, nos domínios da moderna reflexão epistemológica, de uma abordagem normativa do conhecimento humano em geral e da ciência em particular - abordagem preocupada, antes de tudo, em fixar critérios universais, de validade transcultural, com base nos quais se torne possível decidir acerca da aceitabilidade de enunciados ou sistemas de enunciados relativos à realidade. A obra popperiana, a despeito do indisfarçável fascínio de Popper pelo mundo das ciências empíricas, não pertence, em verdade, a esse mundo, nem constitui um empreendimento empírico, algo, de resto, explicitamente reconhecido por seu autor: não se trata, admite Popper, de elucidar em que circunstâncias, naturais ou sociais, o conhecimento científico se tornou possível; não se trata de explicá-lo empiricamente em termos causais ou funcionais, mas sim, tão somente, de justificá-lo à luz de considerações racionais. Popper é claríssimo quanto ao caráter normativo da reflexão epistemológica. Referindo-se ao que chama de "análise lógica do conhecimento científico", tarefa exclusiva dessa reflexão, ele esclarece: "Esta última diz respeito não a questões de fato [...], mas apenas a questões de justificação ou validade [...]. Suas indagações são do seguinte tipo: pode um enunciado ser justificado? Em caso afirmativo, como?" (Popper, 1993, p. 31). A resposta de Popper é bastante conhecida: ao contrário do que imaginavam os empiristas lógicos, os positivistas modernos, a verificação conclusiva das hipóteses universais formuladas pela ciência simplesmente não é possível, pois nenhum conjunto finito de enunciados singulares favoráveis, de exemplos, garantirá logicamente esta verificação: o fato de o enunciado universal "Todo S é P" ter sido confirmado até hoje não exclui, do ponto de vista lógico, a possibilidade de amanhã alguém 
constatar a verdade do enunciado singular proibido por esse universal, a saber, "existe, sim, um S que não é $\mathrm{P}$ ". Mas isso não implica a negação do caráter empírico das hipóteses universais da ciência, nem implica abrir mão da distinção entre conhecimento objetivo, baseado nos fatos, e especulação metafísica. Com efeito, existe, por razões lógicas, uma assimetria entre verificabilidade e falseabilidade de enunciados universais: embora não possamos verificá-los, é possível, sim, através de inferências dedutivas, por meio do modus tollens da lógica clássica, falseá-los a partir da verdade de enunciados singulares com eles incompatíveis: se o enunciado universal "Todo S é P" não pode ser verificado de forma conclusiva por exemplos confirmatórios, não importando o seu número, basta um único registro empírico da existência de "algum $\mathrm{S}$ que não é $\mathrm{P}$ " para refutá-lo em termos conclusivos. Em suma, ao contrário da verificação, o falseamento pode ser dedutivamente estabelecido. Sendo assim, "a teoria que não for refutada por qualquer acontecimento concebível não é científica. A irrefutabilidade não é uma virtude, como frequentemente se pensa, mas um vício" (Popper, 1993, p. 66).

Mas isso não é tudo: da solução popperiana do problema da demarcação, ou seja, do problema de se estabelecer um critério geral para distinguir o conhecimento empírico não só das matemáticas e da lógica, mas também, e, sobretudo, dos sistemas metafísicos, derivam igualmente mandamentos e proibições que deverão governar a conduta dos cientistas. Dito de outra maneira, depois de ter fixado o que pode, ou não, ser considerado conhecimento empírico confiável, Popper agora delibera sobre o comportamento aceitável no mundo da ciência: o objetivo do cientista deve ser, prescreve ele, não "salvar a vida de sistemas insustentáveis, mas, pelo contrário, o de selecionar o que se revele, comparativamente, o melhor, expondo-os todos à mais violenta luta pela sobrevivência" (Popper, 1993, p. 44). Apenas agindo assim, os cientistas poderiam assegurar o conteúdo empírico de suas conclusões e o progresso do conhecimento científico. Impossível ser mais normativo! 
Em Kuhn, o leitor encontrará uma postura bastante diferente. Com efeito, talvez o mérito mais notável da obra desse autor consista exatamente em evidenciar as dificuldades de metodologias filosóficas externas e irredutíveis às disciplinas empíricas particulares, aí se incluindo, com destaque, a história da ciência. Logo na introdução de seu famoso livro acerca da estrutura das revoluções científicas, Kuhn irá sublinhar a importância decisiva da investigação histórica, empírica e não filosófica, numa avaliação crítica das imagens da ciência até então vigentes - imagens, convém lembrar, elaboradas por reflexões epistemológicas essencialmente normativas, mais preocupadas em justificar o conhecimento científico do que em explicá-lo. Nas palavras de Kuhn: "Se a história fosse vista como um repositório para algo mais do que anedotas ou cronologias, poderia produzir uma transformação decisiva na imagem de ciência que atualmente nos domina" (Kuhn, 1975, p. 19). Não cabe aqui apresentar os amplos e variados estudos do mundo da ciência realizados por Kuhn. Gostaríamos apenas de observar o seguinte: nesses estudos, podemos encontrar, misturadas, lado a lado, contribuições muito desiguais no seu valor cognitivo, tais como esboços de uma implausível história teórica da ciência, concebida em termos de uma sequência de revoluções envolvendo dramáticas mudanças nos universos mentais dos cientistas; confusas e incoerentes filosofices relativistas justificadas em nome da preocupação legítima, todavia, numa investigação social - de pensar sociedades humanas distintas em seus próprios termos, evitando assim distorções intelectuais etnocêntricas; interessantes insights acerca dos mecanismos cognitivos presentes no aprendizado da "ciência normal"; e persuasiva descrição de alguns traços distintivos da comunidade científica ao longo da história. $\mathrm{O}$ forte impacto crítico da obra kuhniana e seu papel na "desconstrução" de imagens da ciência normativas e apriorísticas resultarão, sobretudo, desse último elemento, ou seja, do relato etnográfico do mundo da ciência desenvolvido por Kuhn. Vejamos isso mais de perto. 
Os indivíduos que emergem do relato etnográfico kuhniano - formulado inteiramente na linguagem corrente, sem mobilizar conceitos técnicos e generalizações fornecidos por alguma disciplina científica particular, inteligíveis tão somente para os seus praticantes - em nada se parecem com os inquietos e irreverentes cientistas idealizados por Popper: indiferentes ou avessos às intermináveis discussões epistemológicas relativas a fundamentos, garantias e razões últimas, eles preferem, antes, dedicar-se com afinco à resolução de problemas específicos e empiricamente decidíveis no interior de suas áreas de pesquisa, à decifração de "enigmas", na expressão de Kuhn. E nessa atividade científica cotidiana, rotineira, prosaica, os cientistas, longe de assumirem uma postura "crítica" radical, nada aceitando sem garantias racionais, tudo levando ao tribunal da razão, acolhem sem maiores reflexões, tácita e dogmaticamente, todo um conjunto de coisas, tais como generalizações nomológicas, formas mais ou menos padronizadas de resolução de problemas, ontologias minimalistas e valores epistêmicos (precisão, adequação empírica, alcance preditivo etc.). Esta, a "ciência normal", a ciência desenvolvida no dia a dia dos laboratórios por pesquisadores completamente alheios às preocupações normativas sistemáticas dos epistemólogos, indivíduos capazes de estabelecer acordos intersubjetivos amplos e duradouros, sem recorrer a um único argumento formulado no âmbito de uma teoria geral do método com dono ou dona identificável. Nesse plausível relato etnográfico, a parte menos discutível de sua obra, a mais empírica, Kuhn inclui ainda, entre outros aspectos, um cemitério de ideias consensualmente abandonadas, o recurso a manuais na formação básica dos pesquisadores e uma linguagem esotérica compartilhada. Contudo, para os nossos limitados objetivos, basta sublinhar aqui o desinteresse do cientista "normal" em justificações mais gerais do saber científico, esta preocupação quase compulsiva de certa epistemologia:é que tal desinteresse será o estopim da polêmica com Popper. 
Levando em conta a estranha inclinação do intelecto humano de construir no vazio, de povoar o mundo com invencionices mil, geralmente desejáveis, confundindo assim a verdade com o que se prefere - inclinação tantas vezes sublinhada com notável lucidez por grandes espíritos do passado como Montaigne, Erasmo e Bacon -, não há, talvez, elogio mais consagrador para um etnógrafo do que este: "sim, você discorre com exatidão sobre o socialmente real; sim, os fenômenos em questão existem tal como descritos em seu trabalho". E a situação ficará ainda mais lisonjeira, se o aplauso relutante, como diz Shakespeare em algum lugar, vier do adversário, do rival. Não foi outra a experiência vivida pelo Kuhn, etnógrafo da comunidade científica: veio de Popper a admissão mais explícita da realidade da ciência normal. Com efeito, é Popper quem constata: "A ciência normal, no sentido de Kuhn, existe. É a atividade do profissional não revolucionário, ou melhor, não muito crítico: do estudioso da ciência que aceita o dogma dominante do dia; que não deseja contestá-lo". Ou ainda mais claramente: "Afiançarei, portanto, mais uma vez, que o que Kuhn descreve existe, e precisa ser levado em consideração pelos historiadores da ciência" (Popper, 1979, p. 64, 65). Mas esta constatação do fato de que os cientistas reais não costumam ser "criticistas" nas suas práticas cotidianas, não estão minimamente preocupados em justificar à luz de teorias gerais do método, formuladas por epistemólogos profissionais, suas decisões e escolhas na pesquisa, vem acompanhada da crítica mais impiedosa da realidade constatada. É também Popper quem escreve: "O cientista 'normal', a meu juízo, foi mal ensinado [...]. É uma vítima da doutrinação". E, mais adiante: "Só posso dizer que vejo um grande perigo nisso e na possibilidade de tornar-se normal [...] um perigo para a ciência e, na verdade, para a nossa civilização" (op. cit., p. 65-6).

Esta reação passional e destemperada de Popper à etnografia da comunidade científica elaborada por Kuhn - cuja exatidão empírica não 
será questionada, porém, em momento algum - torna particularmente visível a distinção entre abordagens normativas e empíricas do mundo da ciência. Fica óbvio que o ponto de vista popperiano nada tem de empírico: Popper reage como o autoproclamado guardião de certa ideia substantiva do bem, da vida correta, contrariado ao constatar que os cientistas não vêm se comportando de acordo com essa ideia, não vêm sendo virtuosos. Nesta denúncia moral dos cientistas normais, acusados de se revelarem imperdoavelmente crédulos e dogmáticos nas suas atividades profissionais, Popper lembra muito os estridentes críticos da sociedade moderna de inspiração marxista hegeliana (Korsch, Lukács, Marcuse etc.). De fato, em ambos os casos, temos a mesma preocupação compulsiva em traçar o caminho da salvação para seres humanos supostamente cegos, desencaminhados, carentes de orientação. Não ficamos, diga-se de passagem, nem um pouco surpresos com tal convergência, pois a epistemologia popperiana expressa, em verdade, uma profissão de fé aguerrida, sincera, mas algo simplória, nos valores da tradição liberal. Não seria exagerado dizer que o pesquisador "criticista" idealizado por Popper consiste, em ampla medida, numa espécie de defensor doutrinário da "sociedade aberta" contra seus inimigos espirituais. Margaret Masterman (1979) faz certamente um simples registro empírico ao observar que filósofos como Popper "costumam pontificar ainda mais que os teólogos do século XVIII".

Não cumpre realizar aqui um balanço crítico do impacto destrutivo das valorações na teoria geral do método popperiana: isso nos levaria muito longe! Sugerimos apenas que a cegueira diante de aspectos distintivos das ciências naturais mais avançadas - insólita num autor tão familiarizado com elas -, aspectos tais como a relativa autonomia do conhecimento teórico mais fundamental em relação a controles experimentais, parece resultar das premissas volitivas da epistemologia popperiana, da tutela 
ali exercida por razões extracognitivas, morais e políticas. Com efeito, a importância excessiva atribuída às tentativas sistemáticas de falsear hipóteses, que deveriam ser, ao mesmo tempo, gerais e precisas para ampliar ao máximo a possibilidade de falseamentos; a insistência em afirmar o caráter obrigatório dessas tentativas; a condenação violenta e implacável dos que se furtam a elas, tudo isso soa compreensível numa cruzada filosófica em que o infiel assume a figura de teorias presumidamente não testáveis, a exemplo do marxismo e da psicanálise. Nesse sentido, o ponto de vista normativo tutelar, que em Popper abarca tanto a ciência como seus praticantes, termina por comprometer o conteúdo empírico da reflexão epistemológica popperiana, ao reduzi-la a fantasias filosóficas cuja relevância para a ciência e para a "nossa civilização", de fato, parece discutível: a comunidade científica real não evidencia maiores interesses em sermões filosóficos, e este desinteresse não vem, ao que tudo indica, comprometendo o seu indubitável e fascinante sucesso nos últimos quatro séculos. Quanto à "nossa civilização", bem, suspeitamos que ela dispensa totalmente protetores doutrinários obcecados em salvá-la...

Num contraste visível com Popper, Kuhn não formula um conceito normativo de ciência, apoiados no qual, os epistemólogos pudessem avaliar virtudes e pecados de comunidades científicas reais, ou decidir acerca daquilo que deve, ou não, contar como ciência empírica genuína. Em Kuhn, a epistemologia aponta noutra direção, bastante diferente: trata-se de um empreendimento empírico, essencialmente empírico, voltado para a descrição e explicação do mundo da ciência, concebido em termos de um microcosmo social com características próprias - empreendimento esse estranho, em virtude disso, às preocupações normativas de metodologias filosóficas do tipo popperiano. O caráter normativo das ideias de Popper será abertamente censurado por Kuhn. Em suas palavras: "um papel essencial em sua metodologia é desempenhado por trechos que 
só posso interpretar como tentativas de inculcar imperativos morais aos membros do grupo científico" (op. cit., p 31). Entendida como uma investigação empírica, já não caberia à epistemologia operar como verdadeiro tribunal filosófico de última instância na avaliação da ciência e dos cientistas: os epistemólogos, esclarece Kuhn, buscam "explicar as condições de funcionamento da atividade científica, e explicar por que uma atividade funciona não é aprová-la ou desaprová-la" (p. 293). Sendo assim, já não importaria saber, desnecessário dizê-lo, se a ciência confirma ou viola uma "moral mais elevada", constitui ou não a expressão mais perfeita de um conceito normativo de racionalidade, da racionalidade "como parte da nossa concepção da prosperidade humana, da ideia do bem" (Putnam, 1992 , p. 17). Kuhn converge aqui, vale a pena lembrar, com as realistas e sensatas observações de Quine $(1991$; 2006) e Rorty (1988) sobre a completa inutilidade, num mundo onde as ciências empíricas conquistaram o status do conhecimento confiável por excelência, da epistemologia normativa. Nesse sentido, a obra kuhniana representa uma mudança decisiva, embora nem sempre clara e coerente, nos rumos da reflexão epistemológica: o abandono do ponto de vista normativo, preocupado, sobretudo, com questões de validade e justificações gerais do conhecimento humano, exemplarmente ilustrado pelo Popper de A lógica da pesquisa científica, em benefício de abordagens empíricas, interessadas tão somente em explicar as "condições de funcionamento" da pesquisa científica, nelas incluído, com destaque, o ambiente social.

\section{Etnografia da comunidade científica ou crítica filosófica da razão?}

À primeira vista, aceitando-se a autoapresentação encontrada nos livros $A$ ciência em ação e $A$ vida de laboratório, este último escrito em 
parceria com Steve Woolgar, também teríamos em Latour uma clara ruptura com a reflexão epistemológica normativa e apriorística do passado; também em Latour, o normativo cederia lugar ao empírico. Os próprios títulos dos seus livros já parecem anunciar a nova abordagem metodológica escolhida: tratava-se de compreender o mundo da ciência penetrando em seus bastidores, em sua intimidade, acompanhando, o mais de perto possível, suas rotinas, a fim de surpreender a "ciência em ação", a ciência tal como de fato é construída na "vida de laboratório". Segundo Latour, imagens plausíveis e verdadeiras da comunidade científica só poderiam resultar da "observação intensa e participante", de primeira mão, das atividades desenvolvidas no interior dessa comunidade, do "exame profundo do cotidiano de laboratórios", não de sermões filosóficos empiricamente vazios. "Nossas conclusões", assegura Latour com indisfarçável orgulho, estão baseadas tão somente na "descrição meticulosa da pesquisa". Por outro lado, caberia deixar para trás, nesse trabalho de campo, os preconceitos e as crenças apriorísticas acerca da natureza do conhecimento científico, encontrados com frequência entre os "nativos", sobretudo entre os mais letrados, os mais facilmente seduzidos pelo fantasioso discurso epistemológico. Isso significa dizer que, numa etnografia da "tribo" dos cientistas, a autoimagem da "tribo" já não poderia ser aceita sem maiores discussões, pois costuma ser "soprada pela epistemologia". Esta oferecia "um espelho sedutor, mas que só seduz alguns grandes sábios que posam como Claude Bernard", tornando "infelizes todos os outros pesquisadores que não sabem como reconciliar a vida cotidiana do laboratório com aquilo que dizem que eles devem fazer. Esse estudo de campo não é sedutor? Pelo menos não é normativo" (Latour, 1997, p. 29, grifos acrescentados).

Husserl, ilustre representante de uma metafísica social e epistemologicamente desacreditada desde o advento vitorioso da ciência empí- 
rica moderna, ressentida, acuada e na defensiva em decorrência disso, caracterizava os cientistas pela incapacidade de elevar-se à autorreflexão. Já Latour, encontrando essa autorreflexão nos cientistas, declara-a simplesmente ilusória e mistificadora: os pesquisadores mais reflexivos, mais inclinados a leituras filosóficas, seriam os menos aptos a esclarecer o significado de suas práticas profissionais cotidianas, pois permaneceriam prisioneiros das inúteis "armaduras de papelão" oferecidas por uma fantasiosa "epistemologia da verdade": interpelados acerca do que faziam, costumavam responder apelando para duvidosos conceitos epistemológicos, tais como método científico, experiência crucial, falseamento etc., que nada explicariam, nada elucidariam. Coerente com tal conclusão, tanto em A vida de laboratório como em Ciência em ação, Latour sublinhará reiteradas vezes a absoluta necessidade de o etnógrafo da comunidade científica manter-se cético em relação à autoimagem dessa comunidade. No primeiro estudo, podemos ler: "Esse livro pretende ser uma observação de primeira mão do trabalho do saber que utiliza pesquisadores como informantes privilegiados, sem usar o que eles dizem para explicar o que fazem" (Latour, 1997, p. 25). Em Ciência em ação, por sua vez, essa explícita recusa em apelar para os "nativos" quando se trata de explicar o que eles de fato estão fazendo assume o status de uma regra metodológica fundamental, cuja aplicação constituiria verdadeira condição de possibilidade de uma bem-sucedida etnografia do mundo da ciência. Eis a regra: "Entraremos em fatos e máquinas enquanto estão em construção; não levaremos conosco preconceitos relativos ao que constitui o saber [...] essa será a nossa primeira regra metodológica, a que possibilita a nossa viagem" (Latour, 2000, p. 31). E, mais adiante, congratulando-se por haver seguido sua regra: "felizmente decidimos desde o início estudar a atividade de fazer ciência, e não a definição de ciência, dada por cientistas ou filósofos" (p. 286). 
Nessa recusa da explicação intencional das práticas humanas, ou seja, da explicação baseada na elucidação das crenças, disposições, valores e propósitos de indivíduos situados em ambientes sociais particulares, Latour vincula-se objetivamente à mais ambiciosa tradição sociológica, aquela associada aos nomes de Marx e Durkheim, na qual o verdadeiro significado das práticas sociais escapa sempre aos atores individuais ou coletivos, devendo ser buscado, antes, num saber teórico especializado, irredutível às melhores generalizações do conhecimento social de senso comum. E isso pela seguinte razão: apenas por meio desse saber teórico, nele iniciando-se, acessaríamos os determinismos societários, causais ou funcionais, que tornam as práticas sociais plenamente inteligíveis. Assim, por exemplo, nada mais equivocado, nada mais ilusório para historiadores de inspiração teórica marxista que tentar compreender o verdadeiro significado de jornadas revolucionárias através das intenções declaradas de seus protagonistas, se estes ainda viveram na ignorância da obra teórica de Marx, pois teríamos tão somente fantasias "sopradas" por ideólogos. Latour segue na mesmíssima direção, ao procurar entender as práticas dos cientistas "sem usar o que eles dizem para explicar o que fazem". O seu leitor, como o de Marx e Durkheim, não poderá deixar de concluir: o verdadeiro sentido do que as pessoas estão fazendo nas suas interações sociais duráveis permanece inacessível a tais pessoas, escapa à sua compreensão, e deverá, portanto, ser buscado nas obras dos teóricos sociais. Já tivemos a oportunidade de discutir em outro lugar, de forma bastante circunstanciada, com inúmeros exemplos, as enormes e até hoje não superadas dificuldades colocadas para tão ambicioso projeto intelectual, completamente inviável na ausência de um genuíno saber nomológico, ancorado no qual se torne possível deduzir, em condições sociais especificadas, a ação coletiva, dispensando-se, assim, na explicação causal dessa ação, referências obrigatórias aos fins visados subjetivamente pelos indi- 
víduos. Mas deixemos de lado essa dificuldade em Latour, letal, contudo, para ele: existem tantas outras - não cabem todas no espaço limitado deste artigo -, que fomos obrigados a fazer escolhas.

E quais são as características da "tribo" dos cientistas sublinhadas por Latour, após dispensar a autoimagem dessa tribo, após concluir que escaparia aos seus "nativos" o verdadeiro sentido de suas práticas cotidianas? Colocando-se na perspectiva do observador externo sistematicamente preocupado em obter uma "descrição vista do exterior" da vida de laboratório, descrição já não contaminada por definições filosóficas de duvidoso conteúdo empírico, Latour recorrerá à noção de "inscrição", encontrada na obra do filósofo Derrida, para introduzir sentido nas coisas que ali ocorrem. Para o observador externo, assegura ele, "o laboratório é um sistema de inscrição literária", e seus habitantes surgem como nativos de "uma estranha tribo que passa a maior parte do seu tempo codificando, marcando, lendo e escrevendo". Os cientistas e seus auxiliares não estão, é verdade, envolvidos continuamente com a atividade de produzir registros escritos, pois num laboratório eles também podem ser vistos movendo-se entre estranhos objetos, manipulando instrumentos e materiais diversos, sacrificando animais, observando com atenção resultados experimentais, trocando entre si informações enigmáticas, passando instruções etc. Contudo, esclarece Latour, tais atividades constituem elos numa cadeia que desemboca finalmente em inscrições literárias, culminando no estágio da escrita: "Outros tipos de atividades, distantes à primeira vista do domínio da literatura, podem ser interpretados como elementos de uma cadeia que visa a obter uma inscrição" (Latour, 1997, p. 46). Nesse sentido, a escritura, como o ato de marcar, codificar, fichar, produzir figuras, diagramas, relatórios e artigos - um a cada dez dias no laboratório estudado -, se revelaria de fato onipresente, sobretudo no "espaço do escritório", parte do laboratório onde os cientistas estão ocupados com 
leitura e escrita, com suas mesas de trabalho simplesmente abarrotadas de rascunhos de artigos, recortes de artigos, fotocópias de artigos, cartas de colegas, papéis e mais papéis por todo lado. Dessa forma, conclui Latour, a comunidade científica aparece ao observador externo como uma "tribo de leitores e autores que passam dois terços de seu tempo trabalhando em grandes inscritores" (p. 68). E fariam isso, no dia a dia, de "forma compulsiva e, sobretudo maníaca". No laboratório, teríamos "a estranha mania da inscrição".

Do ponto de vista da epistemologia tradicional, caberia distinguir o contexto da descoberta, enquanto conjunto das condições naturais e sociais associadas à gênese de uma ideia, legítimo objeto de investigações empíricas, do contexto da justificação, espaço das razões lógicas e metodológicas de cunho geral, com base nas quais decidimos acerca da aceitabilidade, ou não, de enunciados, sem levar em conta, agora, quaisquer circunstâncias particulares vinculadas às suas origens, domínio exclusivo da reflexão epistemológica. Latour, ao radicalizar a naturalização da epistemologia levada a cabo por Bloor e Barnes antes dele ${ }^{1}$, busca convencer o seu leitor de que, ao acolher essa distinção, endossa-se uma visão transcendental e mistificadora da ciência ou, com mais exatidão, das escolhas e decisões científicas, ao percebê-las como irredutíveis a contextos sociais particulares, ao situá-las fora desses contextos, num fantasioso reino da razão pura, subtraindo-as assim às pesquisas sociais empiricamente orientadas. Mas, se a pesquisa científica mais original e avançada, capaz de revolucionar toda uma área da ciência ou até mesmo criar novas áreas, fosse assimilada ao trabalho literário, concebido nos termos mais

\footnotetext{
${ }^{1} \mathrm{O}$ termo "naturalização" não costuma ser aplicado apenas, esclareçamos, a estudos baseados nas ciências naturais, mas também a abordagens empíricas em geral, servindo para contrastá-las com as abordagens normativas. Por outro lado, é verdade, o Bloor do artigo "Anti-Latour" (1999) não inclui o autor de Ciência em ação no seu programa forte de sociologia do conhecimento. Contudo, Bloor, ao sugerir essa exclusão, tem em mente coisas ditas mais claramente por Latour em textos posteriores aos examinados em nosso trabalho.
} 
genéricos e banais - a noção de inscrição literária não permite distinguir minimamente a bela, plausível e pungente literatura de testemunho de Chalámov das mais grosseiras falsificações da história oficial stalinista, pois nada diz acerca dos conteúdos da "escrita" em questão, nem das qualidades intelectuais e morais dos "escritores" -, então a excepcionalidade do mundo da ciência, a sua aura quase sagrada, estaria de fato em apuros. Em outras palavras, a identificação da pesquisa científica como um labor literário trivial, jamais associado a nada de extraordinário - as qualidades encontradas nos cientistas não seriam essencialmente distintas daquelas "exigidas das pessoas que exercem uma profissão literária: saber escrever, persuadir, discutir" - expressaria, a acreditar em Latour, o esforço sistemático no sentido da completa dessacralização da comunidade científica. Conceber a ciência empírica moderna, tão endeusada em certa reflexão epistemológica, e não só nela, como mais um "sistema de inscrição literária", em vez de assimilá-la a ideias e razões desencarnadas, significaria materializar esta ciência, inseri-la no mundo terreno, profano, despojando-a de privilégios em relação às outras práticas sociais.

O que dizer de semelhante "descrição vista do exterior" da atividade científica? Logo de saída, admitiremos o seguinte: se se entende por fazer inscrições literárias muito simplesmente os atos de produzir caracteres e palavras na superfície de materiais diversos - e não será outro o significado mais geral dessa expressão, caso preservemos os sentidos consagrados pelo uso social dos termos da linguagem corrente nela incorporados -, então as atividades científicas poderão, sim, ser descritas corretamente como uma sistemática e continuada realização de inscrições literárias, pois os cientistas e técnicos, em seu trabalho diário no laboratório, de fato marcam, codificam e escrevem na superfície de materiais diversos - vidro, metais, papéis etc. Portanto, a descrição oferecida por Latour é, sem dúvida, verdadeira. Infelizmente, nem toda descrição verdadeira do mundo 
social será relevante e esclarecedora das coisas que ali se passam. Façamos um experimento mental para tornar isso mais claro: imaginemos um anfiteatro de grandes proporções, no início da exposição de uma severa e talentosa professora. A turma, com as exceções habituais e inevitáveis de sempre, acompanha com atenção e interesse cada palavra dita. De repente, para surpresa de todos e indignação de alguns, um aluno sentado no fundo do anfiteatro se levanta e corre na direção da saída, abandonando a aula. Podemos formular múltiplas descrições verdadeiras do surpreendente episódio, que soarão, contudo, incontestavelmente insatisfatórias. Eis algumas: o aluno, ao correr daquele jeito, queimou calorias e acelerou o seu ritmo respiratório e cardíaco; o aluno gastou um pouco mais a sola de seu sapato; o aluno moveu-se rapidamente na direção da porta do anfiteatro. O leitor não precisará ter familiaridade com a sociologia compreensiva de Weber, lembrar as lúcidas objeções metodológicas ali dirigidas contra o monismo naturalista, nem conhecer a distinção estabelecida na filosofia de Searle $(1991 ; 2000)$ entre "aspectos da realidade independentes da observação e relativos à observação", para notar que tais descrições da ação do nosso aluno imaginário, apesar de verdadeiras, apoiadas em fatos, empíricas, nada esclarecem acerca do sentido de sua ação, pois nada dizem sobre os fins visados subjetivamente pelo rapaz. Dito de outra maneira, podemos perceber de modo intuitivo que elas não respondem à indagação que passaria, contudo, pela cabeça de qualquer pessoa que tivesse assistido à cena: por que, afinal, o aluno saiu às pressas da sala? Qual o sentido de tão insólito comportamento? Na realidade, toda tentativa de descrever este episódio em termos puramente físicos, naturalísticos, sem nenhuma referência às intenções do agente humano em questão, soará irrelevante e insatisfatória, não importa o quanto possa ser verdadeira. E isso por uma razão muito singela: é que, exceto em situações patológicas, nas quais são impelidos por forças naturais irresis- 
tíveis e independentes da consciência e da vontade, os seres humanos costumam agir de forma intencional, deliberada, e os movimentos dos seus corpos respondem a comandos "internos", subjetivos, ainda quando os objetivos perseguidos venham a ser fixados e monitorados no fluxo da vida cotidiana por um habitus (Bourdieu) ou "consciência prática" (Giddens), com raízes sociais, e não por um saber reflexivo. Lidamos aqui com a chamada causação intencional, na qual "conteúdos mentais afetam o mundo" (Searle). Sendo assim, nenhuma descrição genuinamente compreensiva das práticas sociais poderá, de fato, dispensar a elucidação dos propósitos de indivíduos ou grupos envolvidos nessas práticas. Abrir mão dessa elucidação levará tão somente a descrições similares às elaboradas em nosso experimento mental. Nada mais.

Ora, ao descrever as atividades científicas como uma "forma compulsiva e, sobretudo, maníaca" de produzir inscrições literárias, ou seja, caracteres e palavras na superfície de materiais diversos, recusando-se, porém, a elucidar quais os fins perseguidos pelos cientistas ao realizarem tal produção, dispensando-se, por razões metodológicas gerais, de oferecer esse tipo de esclarecimento, Latour acaba fornecendo uma descrição de fato quase fisicalista da vida de laboratório, algo bastante similar às insatisfatórias descrições da ação do aluno imaginário acima apresentadas. Assim, do ponto de vista etnográfico, o uso da noção de "inscrição literária" parece de duvidosa utilidade intelectual, pois, em vez de viabilizar uma "descrição densa", como diria Geertz, das práticas sociais da "tribo" dos cientistas, de torná-las inteligíveis e significativas à luz das intenções reais de seus efetivos protagonistas, termina por reduzi-las a movimentos físicos carentes de sentido, ou seja, etnograficamente inexplicáveis. Não, não foi uma boa ideia tomar emprestado de um filósofo francês a referida noção. Latour faria melhor se deixasse de lado, como, aliás, prometera ao leitor, conceitos filosóficos e, seguindo o bom exemplo dos clássicos 
da antropologia, recorresse em seu relato etnográfico tão somente a conceitos sociais cujos referentes se colocam acima da dúvida sensata. Mas pecaríamos contra a verdade se, aprofundando esta análise, não constatássemos o seguinte: na realidade, a etnografia da comunidade científica levada a cabo por Latour não exclui toda referência a intencionalidades, não reduz as atividades científicas a movimentos corporais, embora de fato rejeite, da forma mais explícita possível, o recurso às intenções dos pesquisadores ao explicar o significado de suas práticas coletivas. Com efeito, após ter descrito o laboratório como um "sistema de inscrição literária", Latour avança, dá mais um passo, e localiza sentidos na produção desse sistema, escapando assim de uma descrição estritamente fisicalista. Mas fará isso, vejam bem, apenas depois de descartar, sem nenhuma cerimônia, crenças e fins declarados do cientista, já identificados aqui como simples fantasias epistemológicas, e imputando intencionalidades e propósitos à vida de laboratório nos quais dificilmente esse cientista se reconheceria. Vejamos isso mais de perto.

Segundo Latour, a vida de laboratório giraria em torno de alguns objetivos fundamentais, revelados nas páginas de seus livros e não nas falas ilusórias de seus "nativos", tais como: o ocultamento sistemático das circunstâncias sociais particulares que estariam não só na gênese, mas também na validação dos enunciados mais solidamente estabelecidos da ciência, os "desmodalizados", os do tipo "caixa-preta", no jargão do nosso autor; o convencimento geral das pessoas de que esses enunciados constituem um saber objetivo acerca da natureza, fruto desejável de pesquisas governadas apenas por regras lógicas e metodológicas gerais de validade transcultural; o silenciamento completo e definitivo de opositores, por meio da mais formidável das retóricas até hoje produzida, a retórica científica, capaz de mobilizar poderosas legiões de aliados, humanos e inumanos, bem como de dividir, isolar e enfraquecer os adversários, acumular 
recursos materiais caríssimos que elevem os custos de possíveis contestações a níveis proibitivos, levando assim ao encerramento de controvérsias em favor dos mais fortes, economicamente mais fortes. Não seria exagerado dizer que $A$ vida de laboratório e Ciência em ação consistem num longo e diversificado argumento, na busca de convencer o leitor de que esses objetivos são de fato perseguidos na "tribo" dos cientistas, não importa o quanto seus "nativos" teimem em negá-lo. Na realidade, o argumento é construído de tal maneira que, em suas negativas, os "nativos" apenas provariam, involuntariamente, o alcance da análise de Latour: a forma de uso dos inscritores, dos aparelhos utilizados para produzir inscrições literárias no laboratório, explicaria a crença epistemológica ilusória dos teimosos "nativos" na possibilidade de enunciados científicos não vinculados a nenhum contexto, pois, "uma vez que se dispõe do produto final - a inscrição -, rapidamente é esquecido o conjunto das etapas intermediárias que tornaram possível sua produção", e a bancada, com tudo o que ali ocorre de material, desordenado e contingente, termina "relegada a segundo plano, chega-se a negligenciar a existência do laboratório. Esta é a hora das 'ideias', das 'teorias' e das razões". Isto lembra bastante, vale a pena observar de passagem, as "estratégias de imunização" ${ }^{2}$ encontradas no marxismo dogmático e obscurantista de Lukács e Korsch: a crença na possibilidade de um conhecimento empírico independente de contextos representaria, em verdade, apenas uma ilusão produzida por um... contexto!

Coloca-se, a esta altura, a questão: se não é possível atribuir a cientistas supostamente imbuídos de fantasias epistemológicas a finalidade de ocultar conexões empíricas, para eles de fato inexistentes, entre os con-

\footnotetext{
${ }^{2}$ Em Tratado da Razão Prática, o filósofo Hans Albert, inspirado na teoria geral do método popperiana, localiza no pensamento dogmático verdadeiras estratégias de imunização, entendendo-se por isso aquelas argumentações que visam sistematicamente subtrair uma teoria à possibilidade de todo e qualquer desmentido empírico (ver Albert, 1976, p. 51, 120).
} 
teúdos da ciência, expressos, sobretudo nos enunciados desmodalizados, e as situações contingentes nas quais transcorre a vida científica, a quem imputaríamos, então, semelhante finalidade? Como Latour não discute os efeitos não premeditados da ação intencional, nem acolhe nenhuma teoria sociológica funcionalista no interior da qual nossas interações sociais duráveis sejam concebidas em termos de um sistema governado por leis ou mecanismos de autorregulação - as duas maneiras conhecidas na análise sociológica de lidar com finalidades, sem precisar recorrer a explicações intencionais da ação -, temos aqui o mais impenetrável dos mistérios. Mas as coisas se complicam ainda mais, quando constatamos que Latour também imputa, em seu relato etnográfico, motivos e finalidades aos indivíduos, sem interpelá-los e, não raro, contrariando abertamente suas falas. Isso acontece, por exemplo, todas as vezes que identifica as atividades intencionais dos pesquisadores com práticas do mundo da política e da economia de mercado. E não se trata, convém esclarecer logo, do uso vago e despretensioso de analogias, tão frequente nas melhores investigações sociais, pois, nesse caso, como já mostramos de forma detaIhada em outro lugar, o autor não perderá tempo com dispensáveis esclarecimentos conceituais, não definirá termos do vocabulário empregado, cujos significados são óbvios no contexto de uso, nem buscará enquadrar de maneira tão completa e exaustiva o seu material empírico com base em suas analogias, como ocorre em Latour. De fato, a conclusão de que o comportamento do pesquisador "é marcado pela notável proximidade com o de um investidor capitalista", pois "o investimento constante e a transformação de credibilidade no laboratório refletem operações econômicas típicas do capitalismo moderno", será acompanhada, no capítulo 5 de $A$ vida de laboratório, de minuciosas discussões conceituais. Num primeiro passo, Latour descarta a utilidade do conceito de norma no estudo empírico da ciência e dos cientistas, sob a alegação de que 
“as normas não são suficientes para explicar a escolha do laboratório, a área da pesquisa ou aquele dado particular". Na verdade, observa Latour, os pesquisadores encontrados "só muito raramente invocaram normas". Em contrapartida, constatou-se "uma clara tendência, sobretudo entre os mais jovens, para descrever o que fazem em termos econômicos". Cabem aqui três observações:

(1) Em estudos etnográficos da ação individual ou coletiva, rentes por definição ao socialmente real em toda sua concretude e complexidade, não faz nenhum sentido operar com disjunções exclusivas de variáveis, ao invés de reuni-las e articulá-las em inventários das causas cada vez mais ricos e completos: não normas ou interesses econômicos, mas sim normas e interesses econômicos, numa lista aberta a novos achados empíricos. E isto soa inescapável num estudo etnográfico que, longe de buscar a ilustração empírica particular dos poderes causais de uma suposta variável independente revelada por um saber nomológico, não cessa de sublinhar o peso decisivo das circunstâncias singulares, das variáveis contextuais, na explicação sociológica do comportamento humano. Em suma, Latour não pode, sem renegar inteiramente teses metodológicas centrais em seu trabalho, sem entrar em contradição com suas próprias conclusões, abordar os interesses econômicos dos indivíduos como o Marx de Lutas de classes na França de 1848 a 1850.

(2) Após ter repetido tantas vezes que não empregaria o que os cientistas "dizem para explicar o que fazem", após ter transformado isso num preceito metodológico fundamental de seu relato etnográfico, Latour não vacila agora em recorrer a tais explicações, em citá-las com aprovação, em usá-las a fim de desmentir uma conclusão que, embora trivialmente verdadeira, quase banal, não é sua nem possui um lugar em seu sistema. Localizamos, tanto em $A$ vida de laboratório como em Ciência em ação, inúmeras passagens nas quais os cientistas afirmam, da maneira 
mais explícita possível, ter aceitado ou recusado enunciados a partir, sobretudo, de testes empíricos de validade geral, e não influenciados por fatores contextuais; mas Latour, nesse caso, rejeitará completamente as explicações de seus "nativos", desqualificando-as como simples fantasias sopradas pela reflexão epistemológica ou induzidas pela forma de uso dos inscritores. O que significa isso? Ficamos com a forte impressão de que o único critério adotado por esse autor para decidir acerca da aceitabilidade, ou não, das falas dos cientistas é tão somente a compatibilidade com o seu próprio sistema: o pesquisador, governado por interesses econômicos, preocupado em fazer investimentos lucrativos, em obter ganhos crescentes, autêntico capitalista, tem um lugar privilegiado nesse sistema e deverá ser identificado de qualquer jeito, custe o que custar, nas coisas ditas pelos "nativos"; já o pesquisador que leva a sério resultados experimentais e, baseado neles, toma decisões, o pesquisador movido em seu trabalho diário pelo mais sensato e prosaico empirismo de senso comum, este surge como verdadeira anomalia, algo incompatível com o sistema criado por Latour, invenção teórica que acha sempre o que procura, só conhece ilustrações e exemplos confirmatórios, jamais é desmentida pelos fatos. Que estranha etnografia!

(3) A conclusão segundo a qual não precisamos incluir nenhuma referência a normas na explicação da conduta dos cientistas enquanto categoria social, apenas porque eles, tomados um a um, não costumam invocá-las ao justificarem escolhas pessoais, inseparáveis de suas trajetórias biográficas, tais como a de um dado laboratório ou área de pesquisa, soa tão extravagante quanto equivocada: seria de fato espantoso se o fizessem, pois normas são regras e preceitos mais gerais, que operam nas comunidades humanas, aí incluída a científica, quase sempre de forma tácita, implícita, e embora bastante úteis na explicação de certas uniformidades ali presentes, dificilmente serão mencionadas pelos 
indivíduos ao formularem justificativas de opções pessoais. Assim, por exemplo, normas da comunidade científica tacitamente aceitas explicam, sem dúvida, por que os pesquisadores, em seu conjunto, incluem referências bibliográficas atualizadas em seus artigos, além de explicitarem a metodologia adotada. Temos aqui um dos incontáveis padrões da vida de laboratório, que permanecerão ininteligíveis, se não levarmos na devida conta o papel das normas - ajustadas aos contextos da ação, claro, pois não estamos sugerindo um fantasioso "determinismo normativo". Contudo, nenhum cientista mencionará, é supérfluo dizê-lo, condicionantes desse tipo para explicar ao "observador externo" por que decidiu publicar numa determinada área de pesquisa. Na elaboração de cada artigo publicado na área escolhida, sua prática será governada por normas, mas não obviamente a escolha em questão. Como Latour pretende elaborar uma etnografia da "tribo" dos cientistas, explicar práticas coletivas, e não escrever biografias circunstanciadas de cada pesquisador, o argumento apresentado para dispensar referências a normas em seu trabalho etnográfico é de fato ruim, muito ruim.

Depois de descartar com tanta superficialidade e ligeireza a utilidade do conceito de norma no estudo etnográfico do mundo da ciência, Latour, prosseguindo em sua discussão conceitual, defende mais uma exclusão em seu sistema. Dessa vez, o excluído será um dos significados correntes, consagrados pelo uso social, da palavra "crédito". Na "tribo" dos cientistas, garante ele, essa palavra não costuma ser empregada no sentido de reconhecimento intelectual, ou seja, não é usada para indicar o grau de respeito, admiração e confiança que alguns pesquisadores podem inspirar aos seus pares, mas sim no sentido econômico de credibilidade enquanto solvabilidade de capital. Segundo Latour, caberia distinguir nitidamente o "crédito-reconhecimento do crédito credibilidade", pois o "crédito como sinônimo de reconhecimento é um problema secundá- 
rio", menor, não desempenhando um papel importante na trajetória dos pesquisadores, não motivando suas principais escolhas e decisões. Assim, "seria nocivo considerar que a obtenção de um reconhecimento constitui o objetivo último da atividade científica". Latour é muito claro ao fixar essa nova oposição conceitual: "o fato de se conceder crédito aos nossos pesquisadores tem, portanto, um sentido mais amplo do que um simples reconhecimento. Em particular, o crédito a que eles fazem referência sugere um modelo econômico integrado de produção de fatos" (p. 215). E o modelo econômico referido aqui não é outro senão o de acumulação capitalista. Com efeito, polemizando contra Hagstrom, que insistia em encontrar algo parecido com a famosa economia da dádiva nas trocas ocorridas entre os cientistas, Latour reafirma a identificação do pesquisador como um "capitalista por excelência": "Parece-nos, ao contrário, que o investimento constante e a transformação de credibilidade no laboratório refletem operações econômicas típicas do capitalismo moderno" (Latour, 1997, p. 229).

O que dizer dessa nova polarização conceitual? Por um lado, como o leitor já terá notado, Latour repete o erro de privilegiar o interesse econômico, particularizado agora na busca de créditos, na explicação da atividade científica, com a exclusão de outra variável supostamente rival, a saber, a preocupação com o reconhecimento. Ora, se para ele até os conteúdos mais gerais do saber científico resultam de contextos particulares, se "a ciência é inteiramente um produto das circunstâncias", não há nenhuma razão para tratar o crédito, no sentido econômico, como se fosse uma daquelas variáveis independentes encontradas nas explicações nomológicas, reais ou imaginárias, pois tais variáveis possuem, por definição, poderes causais irredutíveis a contextos, têm alcance transcontextual. Na perspectiva teórico-metodológica explicitamente assumida por Latour, caberiam apenas conjunções de múltiplas variáveis e não disjunções 
exclusivas: normas, interesses econômicos, necessidade de reconhecimento, tudo isso e muito mais poderia ser incluído, com indubitável proveito, numa abordagem etnográfica sem ilusões nomológicas da "tribo" dos cientistas. Por outro lado, a palavra "reconhecimento" em seus significados usuais, os únicos contemplados por Latour, pode ser empregada para referir uma necessidade psicológica geral, presente nos indivíduos de todas as épocas e lugares, situados nos mais diferentes ambientes sociais, necessidade talvez inseparável da condição humana.

De fato, com exceção de alguns tediosos sistemas filosóficos, nos quais se opera um conceito normativo, e não empírico, de ser humano, e com base nele se prescreve que jamais deveríamos estar sujeitos a coisas externas à alma, destacando-se aqui a opinião alheia, não é difícil localizar na chamada cultura humanista, na riquíssima e imemorial sabedoria em assuntos humanos ali expressa em linguagem corrente, sem o recurso a pedantes jargões esotéricos, incontáveis observações acerca da mencionada necessidade, sempre associada à condição humana. Segundo Pascal, para ficarmos com um exemplo admirável por sua combinação de lucidez e comovente sinceridade, todos desejam "ter admiradores, e mesmo os filósofos querem tê-los, e aqueles que escrevem contra querem ter a glória de ter escrito bem [...] e eu que estou escrevendo isto tenho talvez esta vontade" (Pascal, 2005, p. 269). Se Latour desejava desmistificar a "tribo" dos cientistas, ao identificar em seus "nativos" necessidades e motivações presentes no mais tolo e comum dos mortais, decididamente não foi uma boa ideia abrir mão do conceito de reconhecimento. Na realidade, o uso inteligente e qualificado desse conceito, com as devidas particularizações, permitiria, muito mais que analogias econômicas forçadas e artificiais, tantas vezes sem respaldo efetivo nas falas dos cientistas, não raro desmentidas por tais falas, revelar a dimensão humana, demasiado humana da vida de laboratório. Uma última observação: não se trata de negar o 
fato bastante trivial de que, no mundo moderno, a comunidade científica mantém relações mais ou menos estreitas com o mercado, sobretudo nos Estados Unidos, país onde está localizado o Instituto de pesquisas estudado por Latour. Não queremos brigar com fatos bem estabelecidos, tampouco discutir obviedades. Mas isto não justifica, em absoluto, o esforço compulsivo desse autor no sentido de assimilar a todo custo, operando disjunções tão implausíveis quanto dispensáveis, o pesquisador à figura do investidor capitalista obcecado com ganhos materiais, algo possível apenas, acabamos de vê-lo, quando se negam tolamente fatos não menos triviais.

A outra analogia estabelecida por Latour para explicar, em termos intencionais, a conduta dos cientistas, sem apoio inequívoco em suas falas, sem basear-se no "que dizem para explicar o que fazem", é aquela que se dá com os políticos. Polemizando contra idealizações epistemológicas da comunidade científica, nas quais as "verdades sem paixão" da ciência estão radicalmente separadas e contrapostas às "paixões sem verdade" da política, Latour sublinhará a onipresença da política na ciência: os pesquisadores, assegura ele, "investem suas capacidades políticas no próprio âmago da ciência. Quanto melhores suas qualidades de políticos e de estrategistas, melhor a ciência que produzem" (Latour, 1997, p. 241). E mais adiante, ainda em $A$ vida de laboratório: "uma vez que se admite que as ações dos pesquisadores são orientadas para o campo agonístico, pouco se ganha com a insistência na distinção entre a 'política' da ciência e sua verdade" (p. 268). A ideia de uma semelhança essencial entre as práticas dos cientistas e a dos políticos profissionais também será formulada da maneira mais límpida e explícita possível em Ciência em ação. De acordo com Latour, certas regras em uso na comunidade científica não se distinguiriam essencialmente das encontradas no mundo da política: enfraqueça os inimigos e, se isto não for viável, "paralise o que não puder enfraquecer", não deixe de ajudar "os aliados se eles forem atacados;" 
garanta "comunicações seguras com aqueles que fornecem dados inquestionáveis", mas "se você não tiver certeza de que ganhará, seja humilde e faça declarações atenuadas. De fato, são regras muito simples: são as regras dos velhos políticos" (Latour, 2000, p. 66). Latour formula ainda com mais força essa analogia, ao identificar na atividade científica uma ilustração exemplar de estratégias codificadas por Maquiavel na sua conhecida reflexão sobre a luta política: "essas estratégias 'maquiavélicas' se tornam mais visíveis quando acompanhamos cientistas ou engenheiros" na ciência em construção. Na realidade, esclarece ele, "chamamos de cientistas e engenheiros aqueles que são suficientemente sutis para incluir no mesmo repertório de manobras recursos humanos e não humanos, aumentando assim sua margem de negociação" (op. cit., p. 206). Latour acolhe aqui, obviamente, uma imagem bastante generalizada e realista dos "velhos políticos", dos políticos afeitos a "estratégias maquiavélicas," que nada tem de lisonjeira, de positiva, de moralmente louvável, pois nela tais criaturas aparecem, sobretudo, como indivíduos calculistas e dissimulados, motivados pela vontade de poder e pelo autointeresse, compulsivamente preocupados em derrotar os seus adversários, não importam os meios, tudo instrumentalizando, seres humanos e coisas, a fim de atingir seus objetivos particulares, quase sempre inconfessáveis. Em Lembranças de 1848, esta obra tão notável na sua capacidade de introduzir constantes psicológicas e sociológicas na narrativa de episódios históricos singulares, Tocqueville redescobre a verdade já sublinhada por Maquiavel: "a moralidade dos políticos que regem os assuntos públicos é a mesma em todos os lugares". E, baseado em seu convívio de mais de uma década com certos políticos de seu tempo, acrescenta: "nunca percebi em nenhum deles o gosto desinteressado pelo bem dos homens" (Tocqueville, 1991, p. 102). Tocqueville, como tantos de nós hoje em dia, não tem outra imagem dos "velhos políticos" evocados por Latour em sua analogia. 
Mais uma vez, num contraste forte com o que temos nos admiráveis relatos etnográficos dos grandes observadores da condição humana, entre os quais incluiríamos, sem vacilar, Malinowski e Goffman, Latour simplifica grosseiramente a trama confusa, tortuosa, contraditória e, não raro, surpreendente das interações humanas, reproduzida também na vida de laboratório, reduzindo-a a um estranho "campo agonístico", tão monótono quanto inverossímil, no qual cada indivíduo compartilha com todos os outros, com a totalidade de seus presumidos adversários, objetivos últimos, motivações, interesses e estratégias. A analogia dos cientistas com os "velhos políticos" constitui apenas mais um passo nessa direção: além de escritores compulsivos, quase maníacos, movidos pela necessidade de acumular créditos e fazer investimentos rentáveis, os cientistas, na disputa com colegas ou possíveis discordantes, lançariam invariavelmente mão de estratégias maquiavélicas, inescrupulosas e implacáveis, repetindo assim o comportamento típico dos piores políticos. Mais ainda: a utilização de tais estratégias entraria, em verdade, na própria definição do comportamento cientifico, independendo, portanto de plausíveis variações psicológicas. Isso significa dizer que, na bizarra "tribo" inventada por Latour, tão distanciada do resto da humanidade pela espantosa uniformidade nas motivações e no comportamento diário de seus "nativos", algo talvez encontrável apenas nas páginas de uma subliteratura povoada por inconfundíveis e caricatos vilões, já não parece existir nenhum lugar para tipos psicológicos distintos, de moralidade muito variável, do místico aferrado a princípios ao oportunista sem escrúpulos, nem poderiam coexistir, em um único indivíduo, de forma pacífica ou conflituosa, múltiplas motivações, tais como a busca apaixonada do reconhecimento e da glória intelectuais ou a intensa preocupação em acumular bens e riquezas, motivações essas cujos poderes causais, de resto, podem depender inteiramente das circunstâncias e contingências de uma vida. Em suma, os 
cientistas que emergem do relato etnográfico de Latour foram, sem dúvida, violentamente derrubados do elevado pedestal erguido para eles por certa reflexão epistemológica, mas tal queda não parece tê-los de fato lançado, como supostamente se pretendia, no mundo humano, demasiado humano, compartilhado por todos nós. Na realidade, o cientista-político maquiavélico de Latour soa tão imaginário quanto o cientista-criticista da escola popperiana, com uma diferença, contudo, importantíssima: é que Popper, ao contrário de Latour, jamais pretendeu oferecer um relato etnográfico das práticas reais da comunidade científica, limitando-se tão somente a julgá-las apoiado num conceito normativo de ciência.

É chegada a hora, leitor, de caminharmos para as principais conclusões deste ensaio. Recapitulemos algumas coisas ditas. Tanto em A vida de laboratório como em Ciência em ação, Latour critica a moderna reflexão epistemológica, concebida em termos muito vagos e gerais, sem nenhum aprofundamento em autores ou teses específicas, por seu caráter normativo e apologético, patente em idealizações fantasiosas das práticas reais da comunidade científica. Contra essa abordagem normativa, intrinsecamente incapaz de lidar com fatos de inequívoca relevância no mundo da ciência, como seria o caso da influência de circunstâncias particulares no encerramento de controvérsias, no estabelecimento de enunciados não mais questionados numa determinada área de pesquisa, contra essa abordagem, deixem-nos repetir, Latour pretende contrapor uma etnografia da "tribo" dos cientistas que, resultando tão somente da "observação intensa e participante" da vida de laboratório, estaria apta a contemplar fatos silenciados pelos epistemólogos. Para aqueles que estão convencidos, e estamos entre eles, da completa irrelevância hoje da epistemologia normativa para investigadores realmente envolvidos em pesquisas empíricas, científicas ou não, nada mais louvável: impossível não aplaudir a ideia da troca de tediosos sermões filosóficos, sempre formulados em sis- 
temas datados, com donos ou donas identificáveis, por pesquisas sociais de cunho empírico cujas conclusões se coloquem acima da dúvida razoável. Entretanto, apenas muita predisposição existencial a acolher certas ideias de Latour, apenas a inclinação irresistível a confundir o verdadeiro com o desejável, infelizmente bastante frequente hoje em determinados ambientes acadêmicos, levará alguém a acreditar que semelhante troca de fato ocorreu nos dois livros aqui examinados. Com efeito, a sumária identificação dos cientistas como literatos maníacos que se distinguem ao mesmo tempo pela ganância dos capitalistas e pelo maquiavelismo dos "velhos políticos", a insistência em dissociá-los de normas e princípios capazes de assegurar cooperação e acordos intersubjetivos em nada "agonísticos", a estranha recusa em vislumbrar nas suas ações necessidades e motivações mais elevadas, tais como o "apetite de realidade, raro e difícil de cultivar", ou o desejo de reconhecimento e glória intelectuais, tudo isso implica, obviamente, pelo menos em amplos e influentes setores das ciências sociais - o público mais provável de Latour, talvez o único - uma avaliação moral negativa e injuriosa da comunidade científica. Nada menos etnográfico, nada mais normativo! Na realidade, a presumida "etnografia" da ciência de Latour, longe de resultar da "observação empírica do cotidiano dos laboratórios", parece expressar tão somente a preocupação quase compulsiva de seu autor em desqualificar, moral e intelectualmente, a "tribo" sobre a qual se debruça.

Mas a postura normativa, e não empírica, de aberta e indisfarçável hostilidade em relação à ciência não se revela unicamente nas tendenciosas analogias com os capitalistas e "velhos políticos": em A vida de laboratório e Ciência em ação, ela manifesta-se, em verdade, por todo lado, quase a cada página, a parecer inesgotável. Assim, por exemplo, a comunidade científica também será acusada de ameaçar a igualdade democrática, um dos valores mais prezados por todos nós. É Latour quem 
escreve: "o mundo igualitário dos cidadãos que têm opiniões sobre as coisas transforma-se num mundo não igualitário em que não é possível discordar ou concordar sem um acúmulo de recursos que permita acolher inscrições pertinentes" (Latour, 2000, p. 116). Graças a tão isento registro "etnográfico", ficamos sabendo que os institutos de pesquisa científica mais avançados funcionam como verdadeiros enclaves do pensamento totalitário em sociedades livres e democráticas, nas quais os "cidadãos têm opiniões sobre as coisas". Para o epistemólogo normativo Popper, conforme vimos, o perigo residia apenas numa "ciência normal" que insistia em viver na condenável ignorância do sermão "criticista". O suposto etnógrafo Latour emitirá um julgamento de valor bem mais severo e pessimista: o perigo se mostrava ainda mais grave, além de insanável, pois abrangia agora a totalidade do mundo científico! A valorização moral e política do "mundo igualitário dos cidadãos" não poderia deixar de resultar na completa desvalorização de uma comunidade na qual não já existia lugar para semelhante igualdade. Vejamos um último exemplo da inequívoca presença, em Latour, dessa postura normativa, típica da epistemologia tradicional que ele pretende, entretanto, superar: segundo Latour, o apelo a tecnicismos na literatura científica especializada visaria, sobretudo, afugentar a maioria dos "cidadãos". A utilização de um vocabulário técnico e o recurso à linguagem das matemáticas seriam motivados pela preocupação em proteger, a todo custo, posições já conquistadas. Este o verdadeiro sentido do conhecido hermetismo da linguagem da ciência, sentido invisível aos olhos dos que jamais leram Latour, isto é, da imensa maioria da humanidade. Nas suas palavras: "o acúmulo daquilo que aparece como detalhes técnicos não é coisa sem sentido (...). Um texto científico fica mais difícil de ler; como quando se protege uma fortaleza: não é por prazer, mas para evitar o saque" (op. cit., p. 79). Sendo assim, conclui Latour com indisfarçável animosidade, "melhor ler romances!". 
Mais uma vez, a compulsão normativa estraga tudo, inviabiliza o trabalho empírico, cegando esse filósofo travestido de etnógrafo para alguns fatos óbvios, inegáveis: os cientistas naturais não costumam dispor, em suas pesquisas, ao contrário do que ocorre com os investigadores sociais, de conceitos gerais e abstratos expressos na linguagem corrente, conceitos cujos significados foram fixados pelo uso padrão nas rotinas da vida cotidiana, o que torna seus jargões técnicos tão úteis quanto iniludíveis. A presumida motivação "política" fica por conta exclusiva da imaginação de Latour, sempre inclinada a atribuir razões inconfessáveis às práticas científicas, razões jamais reveladas, é supérfluo dizê-lo, nas falas dos cientistas. Por outro lado, nem a terminologia técnica nem a linguagem matemática constituem obstáculos efetivos para os habitantes da "tribo" dos cientistas, geralmente familiarizados com tais tecnicismos, e estes são os únicos e exclusivos protagonistas de polêmicas científicas. Na realidade, as intimidadoras "fortalezas" mencionadas por Latour existem tão somente para o seu imaginário discordante!

Mas ainda não terminamos: resta ver o confuso e contraditório empirismo que acompanha tal sermão, tornando-o assim menos visível, sugerindo não existir, em verdade, sermão algum, mas apenas pesquisa empírica. Latour costuma censurar os seus adversários por formularem conclusões empiricamente falsas ou vazias, isto é, conclusões sem o devido apoio nas evidências empíricas disponíveis, contrastando-as com o seu próprio trabalho etnográfico, para o qual reivindica um caráter estritamente empírico. Isso aparece, lembremos, na crítica da epistemologia normativa, sempre acusada de esgrimir imagens fantasiosas da ciência, verdadeiras "armaduras de papelão" que não resultam, ao contrário do relato etnográfico de Latour, da "observação empírica do cotidiano dos laboratórios". Os epistemólogos normativos não são, porém, os únicos alvos desta censura metodológica. De fato, outras investigações sociais, 
percebidas como rivais, também estão incluídas. Assim, por exemplo, a sociologia da ciência de Hagstrom, autor que, inspirado no célebre estudo de Mauss sobre a dádiva, insistia em localizar nos intercâmbios entre cientistas um sistema de dádivas e contradádivas, será desqualificada por sua suposta falta de conteúdo empírico. É Latour quem escreve: “com Hagstrom, temos uma explicação do sistema de trocas em termos de normas que é ao mesmo tempo empiricamente indemonstrável e que o próprio autor considera um arcaísmo inexplicável e paradoxal" (Latour, 1997, p. 228 grifos acrescentados). Nessa adesão ao sensato empirismo de senso comum, entendido simplesmente em termos de uma postura metodológica de recurso aos fatos na avaliação das alegações de conhecimento sobre o mundo, algo encontrado tanto no mundo da ciência como em outros ambientes sociais, na adesão a esse empirismo, deixem-nos repetir, Latour em nada difere de seus "nativos", como podemos facilmente constatar ao ler com atenção as páginas de A vida de laboratório e Ciência em ação, nas quais são visibilizadas as posições metodológicas dos pesquisadores (ver Latour, 1997, pp. 115, 120, 122, 126, 146, 147, 154, 155, 168, 217; Latour, 2000, pp. 89, 90, 93, 126, 127, 128, 146, 147). O compromisso de Latour com o empirismo de senso comum revela-se também em outro livro seu, não analisado aqui, intitulado Jamais fomos modernos, no qual Habermas e os pós-modernos são criticados por se absterem, na defesa de suas respectivas teses, "de qualquer estudo empírico" (ver Latour, 1994 , p. 50, 60). Latour sugere, assim, que suas principais conclusões acerca da "tribo" dos cientistas são compatíveis, inteiramente compatíveis com tal empirismo. Nada mais distante da verdade.

Vamos, em primeiro lugar, esclarecer o seguinte: se queremos superar, com base em pesquisas sociais, a distinção epistemológica entre o contexto da descoberta e o contexto da validação, se queremos estabelecer, acima da dúvida razoável, que a validade de um enunciado ou 
sistema de enunciados, aí ousadamente incluídos também os lógicos e analíticos, longe de ser determinada por exigências lógicas e metodológicas gerais (o tal contexto da validação), depende por inteiro das circunstâncias sociais particulares vinculadas à sua gênese, então soa absurdo e contraditório apelar para uma lógica geral de validação de enunciados relativos ao mundo, irredutível por definição a contextos sociais particulares, quando se trata de garantir o acerto de nossos enunciados e/ ou o erro daqueles formulados por adversários. Simples, não? Ora, não é outro o procedimento de Latour, todas as vezes que busca assegurar a validade de suas próprias conclusões sobre a "tribo" dos cientistas, informando ao seu leitor que essas conclusões, num contraste vivo com as de seus oponentes, estão baseadas na "observação empírica do cotidiano dos laboratórios". O empirismo acolhido por Latour funciona aqui, é desnecessário dizê-lo, como um critério geral de validação. Ei-lo: em todas as épocas e lugares, enunciados acerca da realidade são aceitáveis se, e somente se, estiverem de fato apoiados na pesquisa empírica. Assim concebido, e não existe outra maneira de concebê-lo do ponto de vista metodológico, o empirismo endossado por Latour exclui obviamente a tese segundo a qual a aceitabilidade de um enunciado se confunde com sua efetiva aceitação em certos ambientes sociais, pois a mais completa aprovação coletiva de uma crença é compatível, sabemos disso muito bem, com sua não menos completa falsidade empírica. Lembremos, por exemplo, das crenças racistas e sexistas, aceitas de forma tão generalizada no passado em determinados contextos sociais. Este conhecido fato histórico não impede, naturalmente, os críticos atuais de tais crenças de concluírem com acerto que elas jamais foram verdadeiras, não importa a época ou o lugar. Como observa Bloor com sensatez, num livro nem sempre coerente e sensato, precisamos distinguir essas coisas: "pode-se insistir na questão: a aceitação de uma teoria por um grupo social a torna 
verdadeira? A única resposta a ser dada é 'não'" (Bloor, 2009, p. 73). O Latour empirista confesso, em aberta contradição com o Latour teórico social comprometido com a ideia de que a verdade dos enunciados pode ser esclarecida de forma exaustiva pela análise sociológica (sociologia da verdade), não diz nada muito diferente. Assim, por exemplo, ao discutir a questão da aceitabilidade, ou não, dos enunciados da sociologia de Hagstrom, ele não faz referência alguma a contextos sociais particulares, nem subordina essa aceitabilidade a fatores contingentes e existenciais de algum tipo, limitando-se apenas a concluir, conforme já vimos, que tais enunciados soavam inaceitáveis por não terem uma adequada sustentação empírica. E isso é tudo.

Cabe, a esta altura, indagar: o que foi feito do chamado "princípio da reflexividade", sem o qual, como diz Bloor com razão, a sociologia da verdade "seria uma constante refutação de suas próprias teorias"? Qual a relação, afinal, estabelecida por Latour entre gênese e validade no que diz respeito ao seu trabalho? Nos dois livros aqui analisados, nenhuma, simplesmente nenhuma. Na realidade, Latour só manifesta a fé mais inabalável nos fabulosos poderes causais do contexto empírico da descoberta, sumariamente reduzido a contextos sociais, na sua capacidade de explicar "tudo o que importa saber acerca do mundo da ciência," aí incluídas validações e conteúdos do conhecimento científico, quando se trata de negar, com uma rigidez e uma passionalidade que sugerem a ingerência indébita de valorações tutelares, qualquer influência do mencionado empirismo de senso comum nas decisões tomadas pelos cientistas. Somente nesse caso, um empirismo reivindicado pelo próprio Latour na apresentação de seu relato etnográfico, alardeado por ele na crítica de sermões epistemológicos, será radicalmente excluído ao ser identificado em termos de uma ilusão de "nativos" incapazes de compreender o verdadeiro significado de suas práticas, ilusão soprada por epistemólo- 
gos normativos e/ou induzida pelas condições materiais da vida de laboratório. Aceitável enquanto argumento capaz de justificar os discutíveis enunciados de Latour sobre a comunidade científica, o empirismo de senso comum torna-se agora inaceitável, completamente inaceitável na justificação da totalidade dos enunciados da ciência empírica moderna. Espantoso, não? Como explicar tão estranha assimetria num autor que se diz preocupado em superar todas as assimetrias introduzidas pela reflexão epistemológica? Já temos, leitor, elementos para sugerir uma boa hipótese: é que admitir o fato bastante trivial de que os cientistas, neste aspecto indistinguíveis do resto da humanidade, costumam recorrer ao famoso tribunal da experiência quando se trata de justificar suas conclusões sobre o mundo; admitir, portanto, que eles possam ser influenciados, nas suas pesquisas, por sensatas considerações metodológicas irredutíveis a interesses e/ou valores particulares, implica, em verdade, a implosão pura e simples do sistema de Latour. Com efeito, ali apenas há lugar para pesquisadores cujas escolhas são explicáveis unicamente à luz da vontade de domínio e do autointeresse econômico, indivíduos preocupados na totalidade de seu tempo em silenciar, em deixar sem fala, possíveis discordantes. Se Rousseau (1995) tinha razão ao dizer que filósofos vitimados pelo espírito de sistema "não procuram ver as coisas como são, mas como se adaptam ao seu sistema", então a nossa hipótese soa de fato bastante plausível; sobretudo se lembrarmos que o filósofo em questão possui premissas volitivas imperiosas...

\section{Considerações finais}

Uma das coisas que mais impressionam na leitura de Latour é o profundo abismo existente entre a ambição teórica manifestada e os modestíssimos resultados empíricos efetivamente atingidos. A ambição teó- 
rica não poderia ser maior: trata-se de explicar, com base em contextos sociais particulares, os conteúdos e formas de validação da ciência empírica moderna. Nem as verdades da lógica dedutiva deveriam escapar de tão abrangente sociologia da verdade: se, por exemplo, um pesquisador concluía, após ter aceitado a verdade das duas premissas "A ou B" e "não B", pela verdade da conclusão "A", convinha esclarecer que tal conclusão não estava assegurada de jeito nenhum por conexões lógicas, mas sim pelo contexto social. Isso não é pouco, leitor! Confessamos não entender direito o que significa exatamente uma explicação sociológica dos conteúdos da ciência, e os exemplos apresentados por Latour não ajudam muito. Vejamos um deles, o mais detalhado que encontramos, ao qual é dedicado um capítulo inteiro de $A$ vida de laboratório. Trata-se da descoberta de uma substância natural denominada "fator (hormônio) de liberação da tirotropina" ou $\operatorname{TRF}(\mathrm{H})$, extraída de toneladas de tecidos hipotalâmicos fornecidos por abatedouros e sintetizada nos laboratórios. Segundo Latour, o TRF, longe de representar um fato científico universal estabelecido pelas pesquisas empíricas em endocrinologia, válido em todos os contextos sociais, deveria ser pensado inteiramente em termos de uma construção social. Em A vida de laboratório, podemos ler: "o TRF é totalmente uma construção social" (p. 160). E qual o argumento formulado para sustentar tão audaciosa e surpreendente conclusão? Latour parte de duas observações, ambas, sem dúvida, defensáveis: 1) o TRF poderá ser identificado de várias e distintas maneiras, além de significar também coisas bastante diferentes para a vida das pessoas; elas não precisam em absoluto convergir em suas descrições dessa substância; 2) tais variações irão depender, por sua vez, da localização social do observador, do seu lugar em "redes", no jargão técnico de Latour: na perspectiva dos médicos, por exemplo, o TRF estaria relacionado a testes utilizados para verificar possíveis disfunções da hipófise; para pesquisadores, significaria toda uma 
carreira numa "disciplina em plena efervescência"; já os leigos enxergariam no TRF apenas "um pó branco banal". Sendo assim, conclui Latour, "a afirmação do caráter universal da ciência não devia ocultar o fato de que o TRF é 'uma nova substância recentemente descoberta' no contexto de uma rede constituída pelos endocrinologistas"; fora dessa rede, "o TRF não tem existência própria". E isso provaria (empiricamente?) que "mesmo um fato bem instituído perde o sentido quando separado do seu contexto" (ver Latour, 1997, pp. 106, 108). Gostaríamos de fazer dois comentários sobre essa tentativa de Latour de pensar o TRF em termos de uma construção social.

Primeiro: Nos manuais de lógica, os argumentos cujas premissas não possuem nenhuma importância para a conclusão são chamados de "falácias de relevância". Nesse caso, a verdade das premissas não oferece suporte algum à conclusão, quer seja indutivo, quer seja dedutivo. Latour comete exatamente esse tipo de falácia ao concluir que o TRF, enquanto fato científico universal, só tem existência própria e sentido, na realidade, para indivíduos incluídos na rede dos endocrinologistas, pois fora dela o TRF poderá ser descrito de outras maneiras, todas dependentes do contexto social. As premissas do argumento de Latour, admitimos sem maiores discussões, soam plausíveis e baseadas nos fatos. Com efeito, é bastante provável que apenas cientistas sejam capazes de identificar o TRF como um fator de liberação caracterizado por uma determinada fórmula química (Pyro-Glus-His-Pro-Nh). A imensa maioria dos seres humanos, na mais completa ignorância dos segredos da endocrinologia, nada enxergará, certamente, além de "um pó branco banal"; e isto ainda que no recipiente esteja escrito, por extenso e da forma mais legível, o nome do "pó". Por outro lado, essas mudanças significativas nas possíveis descrições do TRF derivam, sim, da distribuição social do conhecimento científico, restrito a certas redes de especialistas, embora pareça um pou- 
co estranho utilizar também o termo "rede" para denominar os milhões de não especialistas em TRF espalhados pelo mundo - o jargão aqui é dispensável, somente atrapalha. Em favor de Latour poderíamos mobilizar uma lista de ilustres pensadores que, ao polemizarem contra um empirismo ingênuo e dogmático, já sublinharam, ao longo dos últimos três séculos, o papel ativo, operoso e construtivo do sujeito epistêmico na produção do conhecimento humano (Kant, Marx, Mannheim, Duhen, Bachelard, Hanson, Piaget etc. etc.). Basta lembrar aqui as fascinantes observações do físico e filósofo francês Pierre Duhen, datadas de fins do século XIX, acerca da impregnação teórica dos resultados experimentais: em virtude dessa impregnação, indissociável do papel de cientista, físicos e leigos veriam sempre coisas muito diferentes no cenário do laboratório. Do ponto de vista teórico, nada, absolutamente nada de novo foi acrescentado por Latour. Mas, voltando às suas premissas: estas não autorizam, de jeito nenhum, a ambiciosa conclusão de seu autor, pois a universalidade do TRF, enquanto fato científico, reside, sobretudo, na validade universal das coisas ditas pelos especialistas sobre essa substância, e tal validade não depende, naturalmente, de uma impossível uniformização das imagens e prováveis usos, entre os seres humanos, do TRF. A fim de tornar isso mais claro, façamos um experimento mental: imaginemos que Latour um triste dia receba, num consultório médico, a pior das notícias: a tomografia computadorizada tirada na semana passada revelara a presença já adiantadíssima de um câncer metastático. O oncologista, com pesar, comunica a Latour que a situação é difícil: infelizmente, com base em enunciados universais da oncologia, era possível concluir, sim, que a tomografia estabelecia limitadas possibilidades terapêuticas. O que faria Latour? Replicaria com despreocupação que o significado e a validade das conclusões de seu médico não possuíam nenhuma universalidade fora da rede dos oncologistas, que o câncer metastático existia, portanto, 
tão somente no interior dessa rede? Latour tentaria sossegar o consternado oncologista lembrando que, para ele, Latour, alguém situado fora da rede dos especialistas em questão, a maldita tomografia constituía tão somente um objeto retangular, feito de plástico, no qual se viam formas brancas num fundo negro? Ou Latour, deixando de lado com sensatez suas filosofices "construtivistas", simplesmente buscaria saber se não the restava de fato alguma esperança de cura? Se ele reagisse assim, algo infinitamente mais provável, caberia repetir o Montesquieu de Cartas persas: "ou não pensas o que dizes, ou então teus atos são superiores a teus pensamentos" (Montesquieu, 2005, p. 149).

Segundo: $\mathrm{O}$ alvo manifesto da sociologia da verdade de Latour é a pretendida universalidade ou generalidade (dois termos da linguagem corrente que podemos intercambiar sem problema) dos enunciados científicos: examinada mais de perto, vista por olhos de etnógrafo, semelhante universalidade revelava-se puramente ilusória. Ora, quando Latour conclui que o "TRF não tem existência própria" fora da rede dos endocrinologistas, pois somente no interior de tal rede faz algum sentido falar na existência de uma nova substância, ele está, na realidade, supondo a aceitabilidade de um enunciado geral, verdadeira "base teórica" de sua conclusão, que pode ser formulado assim: "os indivíduos estão inseridos em redes sociais, e esta inserção moldará o que eles enxergam ou deixam de enxergar no mundo; inexistem, portanto, enunciados acerca da realidade independentes do contexto social". É disso que se trata: Latour, sem dúvida, protestaria com razão se alguém concluísse que sua sociologia da verdade não possui ambições teóricas, ou seja, não almeja obter um conhecimento do geral. O caso do TRF, um simples exemplo, viria apenas confirmar verdades gerais atingidas no âmbito dessa sociologia, ao revelar que até um "fato bem instituído perde o sentido" ao ser isolado de seu contexto social. Coloca-se, incontornável, o problema: o 
que dizer, então, da própria generalização teórica de acordo com a qual todos os enunciados, aí contemplados os chamados universais, os "desmodalizados" no vocabulário de Latour, são inseparáveis de redes sociais particulares, nada valendo ou significando fora delas? Como Latour conseguiria lançar mão dessa generalização, por definição de significado e alcance transcontextuais, válida nos mais diferentes ambientes sociais, sem, ao fazê-lo, desmentir-se da forma mais inapelável? Complicado, não? Na realidade, essa base teórica de Latour funciona como uma autêntica "suposição autorrefutante" e, ao aceitá-la, Latour se vê em apuros: se a tese "todos os enunciados universais são ilusórios por dependerem de contextos sociais" for acolhida como verdadeira, então ela será ilusória, pois consiste num enunciado universal... Com isso, adeus base teórica! Mas as dificuldades não acabaram: além de formular generalizações de escopo transcontextual numa sociologia da verdade que exclui tais generalizações, Latour também recorre, como se não bastasse, piorando ainda mais sua situação, a uma lógica geral de validação de enunciados, o empirismo de senso comum, que não pertence a nenhuma rede social em especial, pois costuma ser utilizada, nas rotinas da vida cotidiana, por indivíduos localizados em todas elas. Quantos universais independentes de contextos sociais num autor tão cético em relação à possibilidade desses universais! O que dizer de tanta confusão e inconsistência intelectuais? De duas, uma: ou o filósofo Bruno Latour não sabe exatamente o que faz ou não leva muito a sério, em verdade, o que diz...

Nos limites deste trabalho, a partir das coisas encontradas em $A$ vida de laboratório e Ciência em ação, já podemos concluir: a polêmica de Latour com os epistemólogos normativos consiste, em verdade, numa disputa insolúvel entre dois sermões filosóficos antagônicos tutelados por valorações últimas e irredutíveis. Os epistemólogos, legítimos herdeiros de uma cultura que remonta a Platão, entusiastas da razão universal, 
acreditam ter descoberto na ciência empírica moderna a expressão mais completa e acabada do conhecimento racional, modelo insuperável para o conjunto da experiência humana. Latour, filósofo francês sintonizado com as valorações da chamada filosofia pós-moderna, leitor de Foucault e Derrida, avesso, existencialmente avesso à ideia normativa de razão, associada a insípidos e tediosos "inimigos da vida", se volta contra a ciência ao supor que a desqualificação moral e intelectual das práticas científicas significaria um golpe mortal em seus adversários: o que restaria, afinal, da moralidade baseada na ideia de razão universal se o seu mais sólido e respeitável bastião, o tão endeusado mundo da ciência, visto mais de perto, visto sem preconceitos e ilusões, se revelasse um mundo governado essencialmente pela vontade de domínio e pelo autointeresse? O que sobraria da razão impessoal, colocada acima dos apetites e das paixões transitórias dos indivíduos de carne e osso, sempre situados em contextos particulares, se descobríssemos que os cientistas, seus mais ilustres guardiões, reúnem, no mesmo passo, características de capitalistas gananciosos e políticos maquiavélicos? Pouca coisa, não? O problema para Latour, este o ponto crucial, é que semelhante discussão filosófica, na qual entusiastas e críticos apaixonados da razão universal travam um interminável e maçante diálogo de surdos, recorrem a sutis e engenhosas argumentações a fim de fortalecer ou destruir convicções normativas que não costumam resultar de nenhum argumento, pouco ou nada tem a ver com as questões abordadas numa pesquisa empírica genuína, e ele, Latour, ao contrário dos epistemólogos normativos, assegura aos seus leitores ter realizado uma pesquisa desse tipo. Repetindo o que diz Kuhn ao criticar com lucidez o sermão popperiano, "explicar por que uma atividade funciona não é aprová-la nem desaprová-la" (Kuhn, 1979, p. 293). Portanto, não caberia a Latour, autoproclamado etnógrafo empírico da "tribo" dos cientistas, crítico implacável da reflexão epistemológica de cunho normativo, 
julgar as crenças e práticas de seus "nativos" com base em valorações, não importa se ético-políticas ou epistêmicas, mas tão somente descrevê-las e explicá-las a partir de investigações efetivamente empíricas, capazes de contemplar o maior número possível de variáveis, contextuais ou não; e isto, acabamos de vê-lo, de fato não ocorreu. Latour informa em algum lugar que os cientistas costumavam apresentá-lo aos visitantes do Laboratório de Neuroendocrinologia do Instituto Salk, onde ele estava desenvolvendo o seu trabalho de campo, como "o nosso filósofo". Impossível discordar de tão realista apresentação.

Luís Augusto de Gusmão é Doutor em Sociologia (USP) e Professor Adjunto IV da Universidade de Brasília, Brasil. \gusmao56@gmail.com

\section{Referências}

1. ALBERT, H. Tratado da razão prática. Rio de Janeiro: Edições Tempo Brasileiro, 1976.

2. BLOOR, D. Conhecimento e imaginário social. São Paulo: Editora Unesp, 2009.

3. BLOOR. Anti-Latour. In: Studies in History and Philosophy of Science, v. 30, n. 1, 1999, pp. 81-112.

4. DUHEN, P. Algumas reflexões acerca da física experimental. Ciência e Filosofia, São Paulo, n. 4, 1989.

5. KUHN, T. S. A estrutura das revoluções científicas. São Paulo: Ed. Perspectiva, 1975.

6. KUHN, T. S. Lógica da descoberta ou psicologia da pesquisa? In: LAKATOS I.; MUSGRAVE, A. (orgs.). A crítica e desenvolvimento do conhecimento. São Paulo, Editora Cultrix / Editora Universidade de São Paulo, 1979.

7. LATOUR, B. Jamais fomos modernos. Rio de Janeiro: Editora 34, 1994.

8. LATOUR, B. A vida de laboratório. Rio de Janeiro: Editora Relume Dumará, 1997.

9. LATOUR, B. Ciência em ação. São Paulo: Editora UNESP, 2000. 
10. MASTERMAN, M. A natureza de um paradigma. In: LAKATOS, I.; MUSGRAVE, A. (orgs.). A crítica e desenvolvimento do conhecimento. São Paulo, Editora Cultrix / Editora Universidade de São Paulo, 1979.

11. MONTESQUIEU. Cartas persas. São Paulo: Nova Alexandria, 2005.

12. PASCAL, B. Pensamentos. São Paulo, Editora Martins Fontes, 2005.

13. POPPER, K. A ciência normal e seus perigos. In: LAKATOS, I.; MUSGRAVE, A. (orgs.). A crítica e o desenvolvimento do conhecimento. São Paulo, Editora Cultrix / Editora Universidade de São Paulo, 1979.

14. POPPER, K . Conjecturas e refutações. Brasília, Editora Universidade de Brasília, 1982.

15. POPPER, K . A lógica da pesquisa científica. São Paulo, Ed. Cultrix, 1993.

16. PUTNAM, H. Razão, Verdade e História. Lisboa: Publicações Dom Quixote, 1992.

17. QUINE, W. V. (1991). "A epistemologia naturalizada". In: Carrilho, M. M. (org.). Epistemologia: posições e críticas. Lisboa: Fundação Calouste Gulbenkian.

18. QUINE, W. V. Two Dogmas of Empiricism. In: MARTINICH, A. P.; SOSA, D. Analytic Philosophy. An Anthology. Victoria, Blackwell Publishing, 2006.

19. RORTY, R. A Filosofia e o Espelho da Natureza. Lisboa, Publicações Dom Quixote, 1988.

20. ROUSSEAU, J. J. Emílio. São Paulo: Livraria Martins Fontes, 1995.

21. SEARLE, J. Intentionalistic Explanations in the Social Sciences. In: Philosophy of the Social Sciences, v. 21, n. 3, Sep. 1991 (pp. $332-44$ ).

22. SEARLE, J. Mente, Linguagem e Sociedade. Rio de Janeiro, Ed Rocco, 2000.

23. TOCQUEVILLE, A. Lembranças de 1948. São Paulo, Companhia das Letras, 1991.

Recebido: 04.02.2016

Aceite final: 11.06.2016 